\title{
Adsorption and surface reactions of acetaldehyde on alumina-supported noble metal catalysts
}

\author{
J. Raskó and J. Kiss* \\ Reaction Kinetics Research Group of the Hungarian Academy of Sciences at the University of Szeged, H-6701 Szeged, P.O. Box 168, Hungary
}

Received 4 November 2004; accepted 3 December 2004

\begin{abstract}
Adsorption and further surface transformations of acetaldehyde on $\mathrm{Al}_{2} \mathrm{O}_{3}$-supported noble metal catalysts were studied by FTIR spectroscopy. Two forms (H-bridge bonded and bonded to Lewis sites) of molecularly adsorbed acetaldehyde were detected. $\beta$-aldolization of acetaldehyde into crotonaldehyde was observed already at $300 \mathrm{~K}$ on all surfaces investigated. The formation of adsorbed crotonaldehyde depended on the temperature and on the nature of the metal. The gas phase products (crotonaldehyde, benzene, hydrogen, ethane, ethylene and acetylene) were analyzed by mass spectrometer. Their appearance in the gas phase and their amounts depended on the nature of the metal and on the temperature.
\end{abstract}

KEY WORDS: acetaldehyde adsorption; $\mathrm{Al}_{2} \mathrm{O}_{3}$-supported Pt, $\mathrm{Rh}$, Au catalysts; surface species; gas phase products; FTIR; MS.

\section{Introduction}

The demand for alternative sources of energy initiated the studies on steam reforming of ethanol producing $\mathrm{H}_{2}$-rich (CO-free) gas mixture [1-13]. The use of $\mathrm{H}_{2}$ as fuel ensures the cleanest source of energy with practically zero emission of polluting gases. If, however, $\mathrm{H}_{2}$ is be produced catalytically, acetaldehyde appears both in the gas phase and in the adsorbed layer [14]. The presence of acetaldehyde in the exhaust would be dangerous to the environment because of its potential carcinogen effects [15]. From this point of view the catalytic transformation of acetaldehyde into less hazardous materials seems to be very important.

$\mathrm{Al}_{2} \mathrm{O}_{3}$-supported noble metal catalysts proved to be the most active in producing $\mathrm{H}_{2}$ from ethanol + water gas mixture [13]. Accordingly, acetaldehyde (considered as the indicator of hydrogen production) may be formed most effectively on these catalysts. In the present work we publish data on the adsorption and further surface reactions of acetaldehyde on $\mathrm{Al}_{2} \mathrm{O}_{3}$-supported noble metals. Our primary aim was to assign the surface species and gas phase products of the interaction between acetaldehyde and these catalysts and to probe the effectivity of these catalysts in the catalytic transformation of acetaldehyde.

\section{Experimental}

$\mathrm{Al}_{2} \mathrm{O}_{3}$ was the product of Degussa $\left(\mathrm{P} 110 \mathrm{C} 1,100 \mathrm{~m}^{2} /\right.$ g). About $1 \% \mathrm{Pt} / \mathrm{Al}_{2} \mathrm{O}_{3}$ and $1 \% \mathrm{Rh} / \mathrm{Al}_{2} \mathrm{O}_{3}$ catalysts were prepared by impregnating of $\mathrm{Al}_{2} \mathrm{O}_{3}$ with an aqueous

\footnotetext{
* To whom correspondence should be addressed.
}

E-mail: jkiss@chem.u-szeged.hu solution of $\mathrm{H}_{2} \mathrm{PtCl}_{6} \times 3 \mathrm{H}_{2} \mathrm{O}$ (Reanal) and with that of $\mathrm{RhCl}_{3} \times 3 \quad \mathrm{H}_{2} \mathrm{O}$ (Johnson Matthey), respectively. The impregnated powders were dried at $383 \mathrm{~K}$ for $3 \mathrm{~h}$. $\mathrm{Al}_{2} \mathrm{O}_{3}$ supported $\mathrm{Au}$ catalyst was made by a deposition-precipitation method. Chloroauric acid $\left(\mathrm{HAuCl}_{4} \cdot\right.$ aq p.a. $49 \%$ Au, Fluka AG) was first dissolved in triply distilled water. After the $\mathrm{pH}$ of the $\mathrm{HAuCl}_{4}$ aqueous solution was adjusted to $7.5 \mathrm{pH}$ adding $1 \mathrm{M} \mathrm{NaOH}$ solution, the fine powder of the supporting oxide was suspended and kept at $343 \mathrm{~K}$ for $1 \mathrm{~h}$ with continuous stirring. The suspension was aged for $24 \mathrm{~h}$ at room temperature and washed with distilled water repeatedly, dried at $353 \mathrm{~K}$ and then calcined in air at $573 \mathrm{~K}$ for $4 \mathrm{~h}$.

Acetaldehyde was of $99.8 \%$ purity (Riedel de Haen) and it was used after a freeze and pump purification process.

For IR studies the catalysts powders were pressed onto a Ta-mesh $\left(30 \times 10 \mathrm{~mm}, 5 \mathrm{mg} / \mathrm{cm}^{2}\right)$. The mesh was fixed to the bottom of a conventional UHV sample manipulator. It was resistively heated and the temperature of the sample was measured by $\mathrm{NiCr}-\mathrm{Ni}$ thermocouple spot-welded directly to the mesh. The pre-treatments of the samples were performed in a stainless steel UV IR cell (base pressure $1.33 \times 10^{-5} \mathrm{~Pa}$ ): the samples were heated in $1.33 \mathrm{hPa}$ of $\mathrm{H}_{2}$ up to $573 \mathrm{~K}$ and it was kept at this temperature for $1 \mathrm{~h}$. This was followed by degassing at the same temperature for $30 \mathrm{~min}$ and by cooling the sample to the temperature of the experiment.

Infrared spectra were recorded with a Genesis (Mattson) FTIR spectrometer with a wavenumber accuracy of $\pm 4 \mathrm{~cm}^{-1}$. Typically 136 scans were collected. The whole optical path was purged by $\mathrm{CO}_{2}$ - and $\mathrm{H}_{2} \mathrm{O}$-free air generated by a Balston 75-62 FT-IR purge gas generator. The spectrum of the pre-treated sample 
(background spectrum) and the actual vapor spectrum were subtracted from the spectrum registered in the presence of vapor. All subtractions were taken without use of a scaling factor $(\mathrm{f}=1.000$ ). Mass spectrometric analysis was performed with the help of a QMS 200 (Balzers) quadrupole mass-spectrometer. The volume around the head of QMS 200 was continuously evacuated and it was connected with the UV IR cell via a leak valve producing $6.65 \times 10^{-4} \mathrm{~Pa}$ around the MS head when reacting gases were present in the cell. The changes in the signal intensity of the main fragments of acetaldehyde and the possible products were followed by mass spectrometer. With the help of a home made algorithm one can calculate the intensity characterizing only the given product (generally the most intense fragment signal of a molecule) by taking into account the contributions of any other fragments to this signal. The contributions were calculated on the basis of the intensity ratios of the fragments characteristics of the individual molecules. The intensity ratios measured in our system during MS analyses of the starting materials and the possible products did not differ considerably from the intensity ratios published in the literature.

\section{Results and discussion}

The adsorption of $1.33 \mathrm{~Pa}$ acetaldehyde at $300 \mathrm{~K}$ on reduced catalysts resulted in the IR spectra collected on figure 1. The bands at $2963 \mathrm{~cm}^{-1}\left(\mathrm{v}_{\mathrm{as}}\left(\mathrm{CH}_{3}\right)\right)$, at $2923 \mathrm{~cm}^{-1}\left(v_{\mathrm{s}}\left(\mathrm{CH}_{3}\right)\right)$, at $1692 \mathrm{~cm}^{-1} \quad(\mathrm{v}(\mathrm{C}=\mathrm{O}))$, at $1451 \mathrm{~cm}^{-1}\left(\delta_{\mathrm{as}}\left(\mathrm{CH}_{3}\right)\right)$ and at $1391 \mathrm{~cm}^{-1}(\delta(\mathrm{CH}))$ belong to molecularly adsorbed acetaldehyde (I). The appearance of other bands is the consequence of surface transformation of acetaldehyde. Thus, the bands at
$1635 \mathrm{~cm}^{-1}(v(\mathrm{C}=\mathrm{O}))$, at $1609 \mathrm{~cm}^{-1} \quad(v(\mathrm{C}=\mathrm{C}))$, at $1270 \mathrm{~cm}^{-1}(\delta(\mathrm{C}-\mathrm{H}))$ and at $1172 \mathrm{~cm}^{-1}(\mathrm{v}(\mathrm{CC}))$, characteristic for crotonaldehyde (II), are the results of $\beta$ aldolization of acetaldehyde on the surfaces. The reduction of acetaldehyde (with the help of protons in the surface $\mathrm{OH}$ groups) to ethoxy (IV) caused the appearance of the bands at $2874 \mathrm{~cm}^{-1}(\mathrm{v}(\mathrm{CH}))$ and at $1059 \mathrm{~cm}^{-1}(\mathrm{v}(\mathrm{CO}))$.

The relevant shift down of the acetaldehyde $\mathrm{C}=\mathrm{O}$ stretching from $1730 \mathrm{~cm}^{-1}$ (observed in the gas phase) to $1692 \mathrm{~cm}^{-1}$ suggests that part of acetaldehyde is adsorbed on Lewis sites through one of the oxygen lone pairs. The negative features at 3783,3730 and $3680 \mathrm{~cm}^{-1}$, as well as the broad absorptions centered at 3584$3570 \mathrm{~cm}^{-1}$ show that another part of acetaldehyde may adsorb through hydrogen bridge bonding with $\mathrm{OH}$ groups of the catalysts.

With the increase of acetaldehyde pressure to $1.33 \mathrm{hPa}$ the intensities of the bands increased and shifts in the positions of some bands could be observed (figure 2). The band due to $v(\mathrm{C}=\mathrm{O})$ of acetaldehyde became dominant and shifted upward (from 1692 to $1702 \mathrm{~cm}^{-1}$ ) in $1.33 \mathrm{hPa}$. A downward shift (from 1391 to $1379 \mathrm{~cm}^{-1}$ ) was observed in the position of $\delta(\mathrm{CH})$ band of acetaldehyde. At $1.33 \mathrm{hPa}$ a new band at $1132 \mathrm{~cm}^{-1}$ due to $v(\mathrm{CC})$ of acetaldehyde could be detected. Most of the bands due to adsorbed crotonaldehyde $(v(\mathrm{C}=\mathrm{O}), v(\mathrm{C}=\mathrm{C}), \delta(\mathrm{CH}))$ shifted to higher wavenumbers, while the $1172 \mathrm{~cm}^{-1}$ band $(v(\mathrm{CC})$ of crotonaldehyde) showed a downward shift to $1151 \mathrm{~cm}^{-1}$ with the increase of acetaldehyde pressure. New band at $1594 \mathrm{~cm}^{-1}$ (possibly due to $v(\mathrm{C}=\mathrm{C})$ of crotonaldehyde) was developed, when the pressure was increased from $1.33 \mathrm{~Pa}$ to $1.33 \mathrm{hPa}$. Interestingly, the positions of the

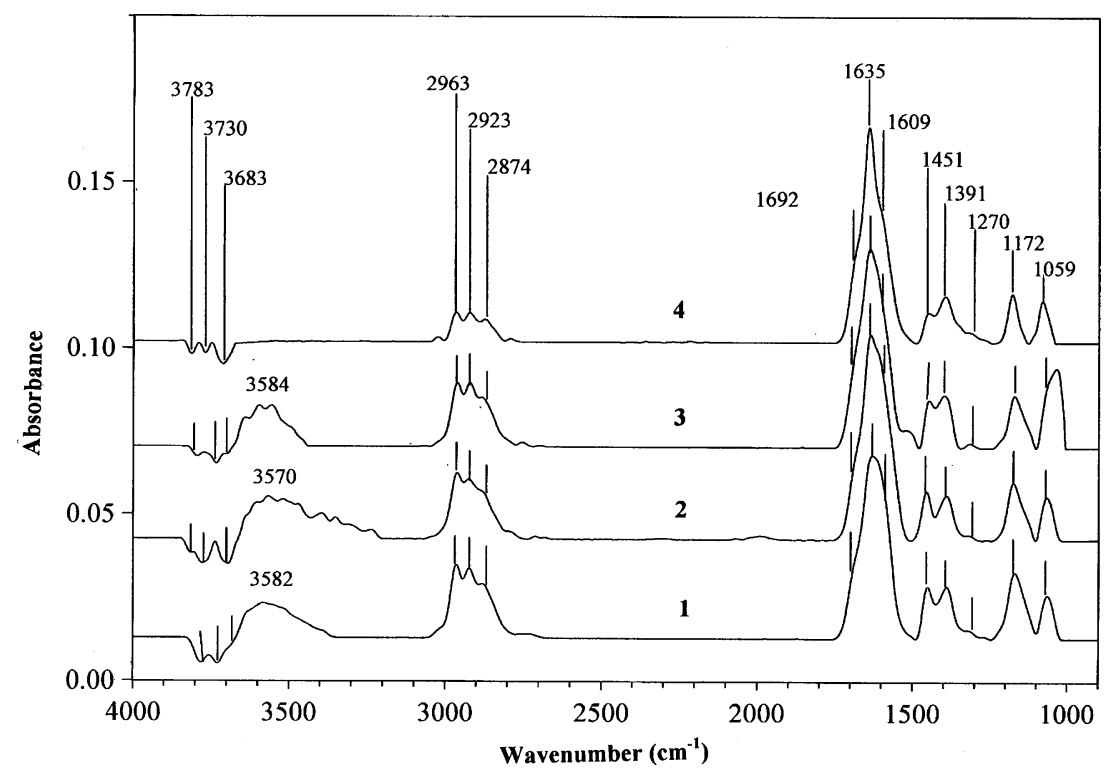

Figure 1. IR spectra registered at $300 \mathrm{~K}$ in the adsorption of $1.33 \mathrm{~Pa}$ acetaldehyde on reduced catalysts: $1-\mathrm{Al}_{2} \mathrm{O}_{3} ; 2-1 \% \mathrm{Rh} / \mathrm{Al}_{2} \mathrm{O}_{3} ; 3-1 \% \mathrm{Au} /$ $\mathrm{Al}_{2} \mathrm{O}_{3}$ and $4-1 \% \mathrm{Pt} / \mathrm{Al}_{2} \mathrm{O}_{3}$. Adsorption time was $15 \mathrm{~min}$. 


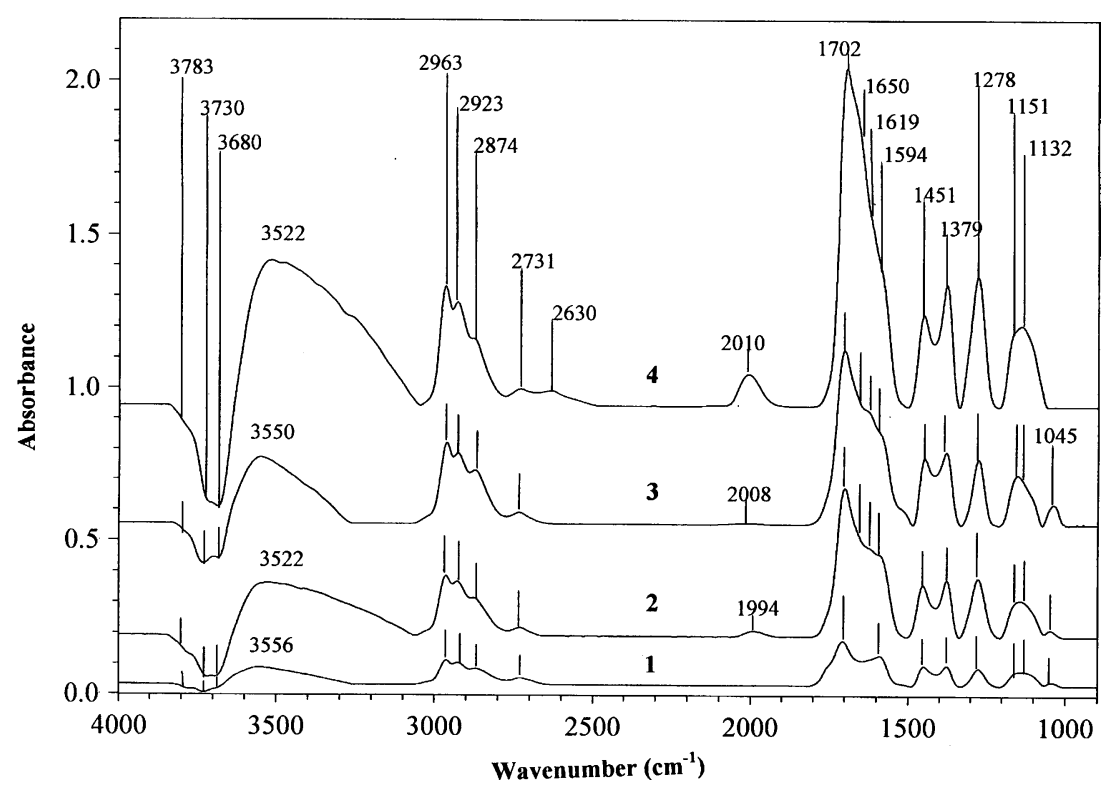

Figure 2. IR spectra registered at $300 \mathrm{~K}$ in the adsorption of $1.33 \mathrm{hPa}$ acetaldehyde on reduced catalysts: $1-\mathrm{Al}_{2} \mathrm{O}_{3} ; 2-1 \% \mathrm{Rh}_{2} / \mathrm{Al}_{2} \mathrm{O}_{3} ; 3-1 \%$ $\mathrm{Au} / \mathrm{Al}_{2} \mathrm{O}_{3}$ and $4-1 \% \mathrm{Pt} / \mathrm{Al}_{2} \mathrm{O}_{3}$. Adsorption time was 15 min.

negative features were unaltered, the centers of the broad absorptions, however, shifted to lower wavenumbers with the increase of acetaldehyde pressure. On the spectra of metal containing $\mathrm{Al}_{2} \mathrm{O}_{3}$ catalysts very small bands at $2010-1994 \mathrm{~cm}^{-1}$ became detectable, which are probably due to $\mathrm{H}$-perturbed $\mathrm{CO}$ adsorbed on the metal sites.

In the next experiments the adsorbed acetaldehyde layer (produced by the adsorption of $1.33 \mathrm{hPa}$ acetaldehyde at $300 \mathrm{~K}, 15 \mathrm{~min}$ and subsequent evacuation at $300 \mathrm{~K}$ for $5 \mathrm{~min}$ ) was heated up during evacuation to different temperatures, kept at these temperatures for $1 \mathrm{~min}$ and cooled down to $300 \mathrm{~K}$. The spectra developed by these treatments and registered at $300 \mathrm{~K}$ on $1 \% \mathrm{Pt} /$ $\mathrm{Al}_{2} \mathrm{O}_{3}$ were collected in figure 3 .

The intensities of the bands characteristic for $\mathrm{C}-\mathrm{H}$ stretching vibrations in the range of $3000-2700 \mathrm{~cm}^{-1}$ continuously decreased with the increase of the temperature. Their traces, however, could be detected even after the treatment at $673 \mathrm{~K}$. In the $1800-900 \mathrm{~cm}^{-1}$ range the bands at $1697 \mathrm{~cm}^{-1}(\mathrm{v}(\mathrm{C}=\mathrm{O})$ of acetaldehyde), at $1382 \mathrm{~cm}^{-1}(\delta(\mathrm{CH})$ of acetaldehyde $)$ and at $1131 \mathrm{~cm}^{-1}$ ( $v(\mathrm{C}=\mathrm{C})$ of acetaldehyde), as well as the bands at $1604 \mathrm{~cm}^{-1}(v(\mathrm{C}=\mathrm{C})$ of crotonaldehyde $)$, at $1284 \mathrm{~cm}^{-1}(\delta$ $(\mathrm{C}-\mathrm{H})$ of crotonaldehyde) and at $1168 \mathrm{~cm}^{-1}(\mathrm{v}(\mathrm{CC})$ of crotonaldehyde) drastically decreased at $373 \mathrm{~K}$; at and above $423 \mathrm{~K}$ the bands at 1697, 1614, 1382 and $1284 \mathrm{~cm}^{-1}$ were not observed. From $423 \mathrm{~K}$ new bands at $1564 \mathrm{~cm}^{-1}$ (possibly due to acetate) and at 1478 and $1350 \mathrm{~cm}^{-1}$ (tentatively assigned to carbonates) were detected, the intensities of which decreased with the further increase of the temperature. Spectral features due to hydrogen bridge bonding (not shown) were observed up to $523 \mathrm{~K}$, after the treatment at $573 \mathrm{~K}$ and above these features disappeared from the spectra. The intensity of the $2010 \mathrm{~cm}^{-1}$ band showed a maximum at $373 \mathrm{~K}$, it could be, however, detected even after the treatment at $673 \mathrm{~K}$. Similar behavior of the bands were experienced on other noble metal containing catalysts. The spectral features due to H-bridge bonding disappeared already at $423 \mathrm{~K}$ and there was no band between 2100 and $2000 \mathrm{~cm}^{-1}$ on the spectra of pure $\mathrm{Al}_{2} \mathrm{O}_{3}$.

During the above treatments the desorbed molecules were analyzed by mass spectrometer. Data for the main products from different catalysts were collected on figures 4 and 5. Acetaldehyde desorption shows a maximum at about $400 \mathrm{~K}$, however, the desorption of it was detected even above this temperature: on $\mathrm{Al}_{2} \mathrm{O}_{3}$ and on $1 \% \mathrm{Au} / \mathrm{Al}_{2} \mathrm{O}_{3}$ catalysts a second maximum at $600 \mathrm{~K}$ was also observed in molecular acetaldehyde desorption (figure 4a). These findings are in harmony with the IR data showing two forms of adsorbed molecular acetaldehyde on these surfaces.

According to IR data crotonaldehyde $\left(\mathrm{CH}_{3} \mathrm{CH}=\mathrm{CHCHO}\right)$ was produced by $\beta$-aldolization of acetaldehyde already at $300 \mathrm{~K}$. Its desorption depicted a maximum at $400 \mathrm{~K}$ from all catalysts (figure $4 \mathrm{~b}$ ).

Among the desorption products benzene was detected with two maxima at $440 \mathrm{~K}$ and at $623 \mathrm{~K}$ (figure $4 \mathrm{c}$ ). The formation of benzene has been formerly detected in the interaction of ethanol with $\mathrm{Pt} / \mathrm{CeO}_{2}$ [16] and it was interpreted as the formation of acetaldehyde (the product of dehydrogenation of ethanol), was followed by subsequent production of crotonaldehyde (the result of $\beta$-aldolization of acetaldehyde) and their reaction:

$$
\begin{aligned}
& \mathrm{CH}_{3} \mathrm{CHO}_{(\mathrm{a})}+\mathrm{CH}_{3} \mathrm{CH}=\mathrm{CHCHO}_{(\mathrm{a})} \\
& \quad \rightarrow \mathrm{CH}_{3} \mathrm{CH}=\mathrm{CH}-\mathrm{CH}=\mathrm{CH}-\mathrm{CHO}_{(\mathrm{a})}+\mathrm{H}_{2} \mathrm{O}
\end{aligned}
$$



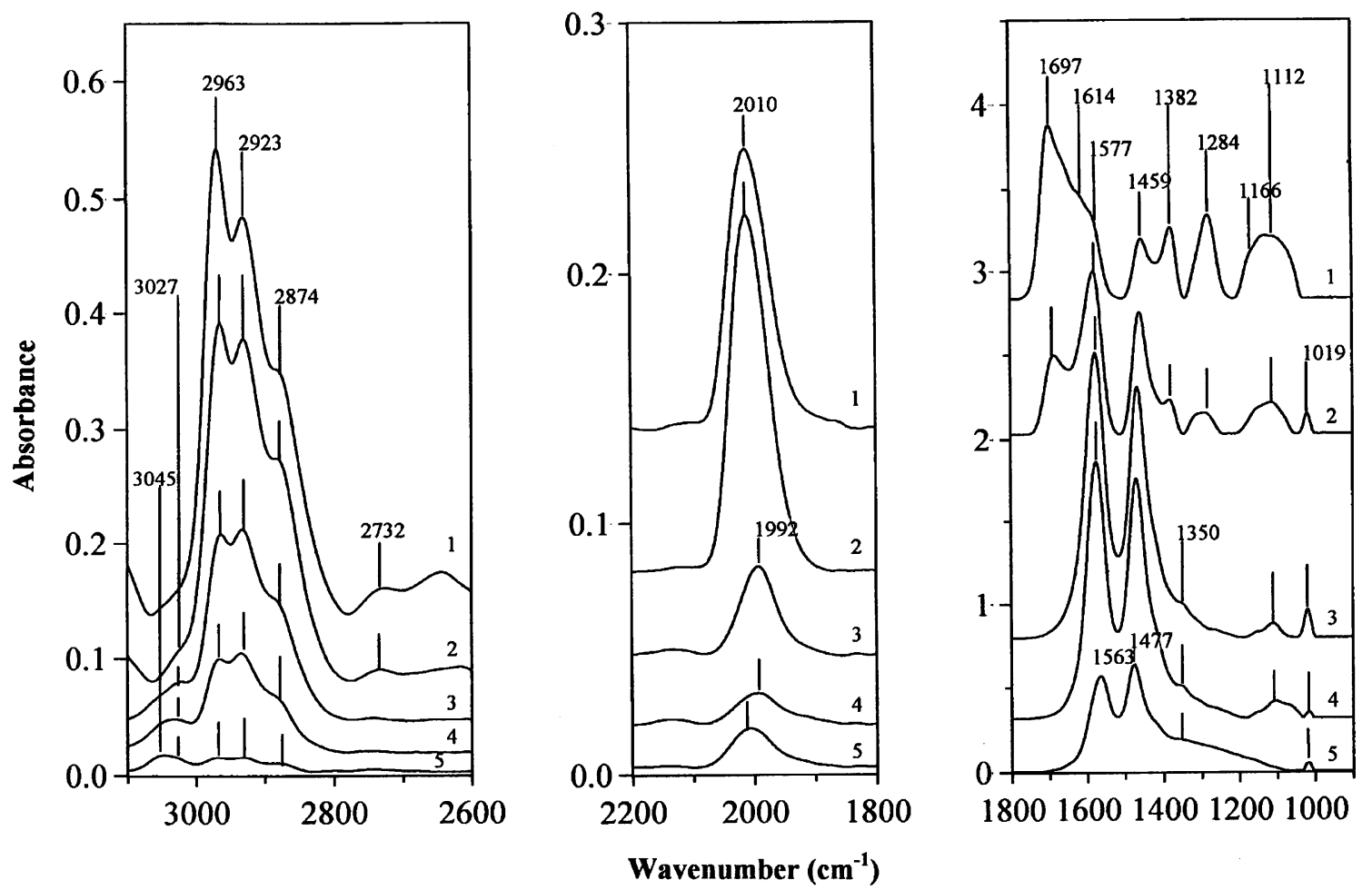

Figure 3. IR spectra taken at $300 \mathrm{~K}$ after different heat treatments in vacuum (see text) of adsorbed acetaldehyde layer on $1 \% \mathrm{Pt} / \mathrm{Al}_{2} \mathrm{O}_{3}$ : $1-300 \mathrm{~K} ; 2373 \mathrm{~K} ; 3-473 \mathrm{~K} ; 4-573 \mathrm{~K}$ and $5-673 \mathrm{~K}$.
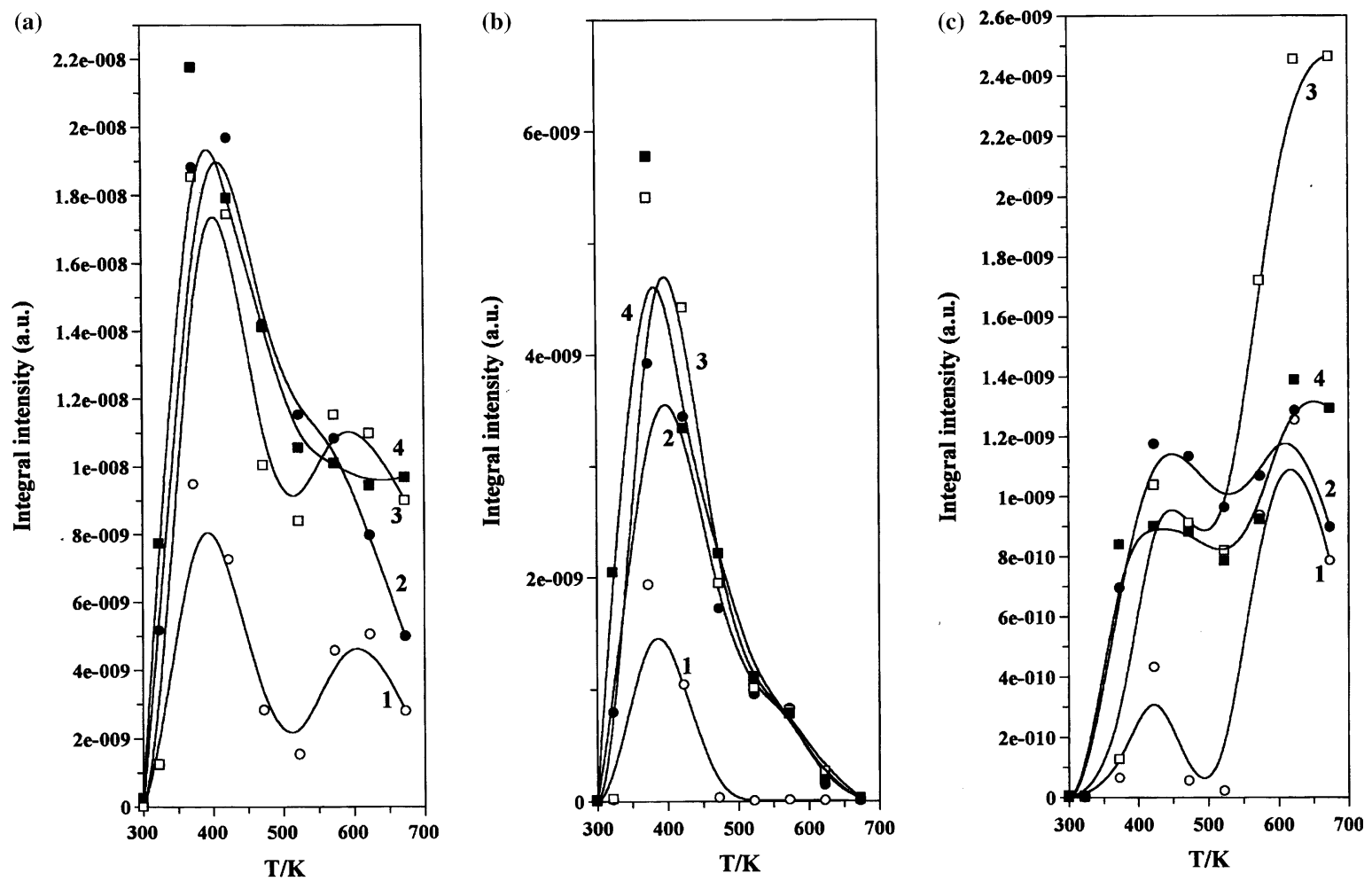

Figure 4. Formation of some gas phase products (monitored by MS) during the heat treatments (see text) of adsorbed acetaldehyde layer on reduced catalysts: $1-\mathrm{Al}_{2} \mathrm{O}_{3} ; 2-1 \% \mathrm{Rh} / \mathrm{Al}_{2} \mathrm{O}_{3} ; 3-1 \% \mathrm{Au} / \mathrm{Al}_{2} \mathrm{O}_{3}$ and $4-1 \% \mathrm{Pt} / \mathrm{Al}_{2} \mathrm{O}_{3}$. (a) acetaldehyde; (b) crotonaldehyde and (c) benzene. 
(a)

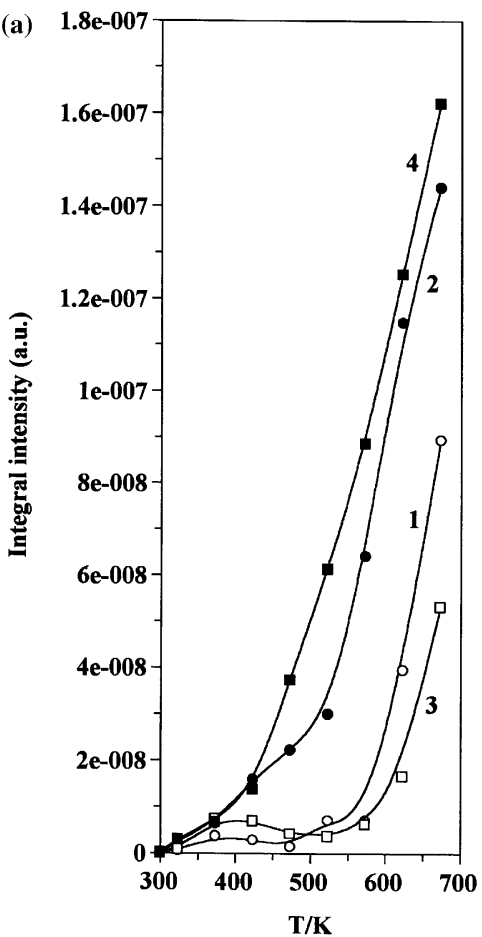

(b)

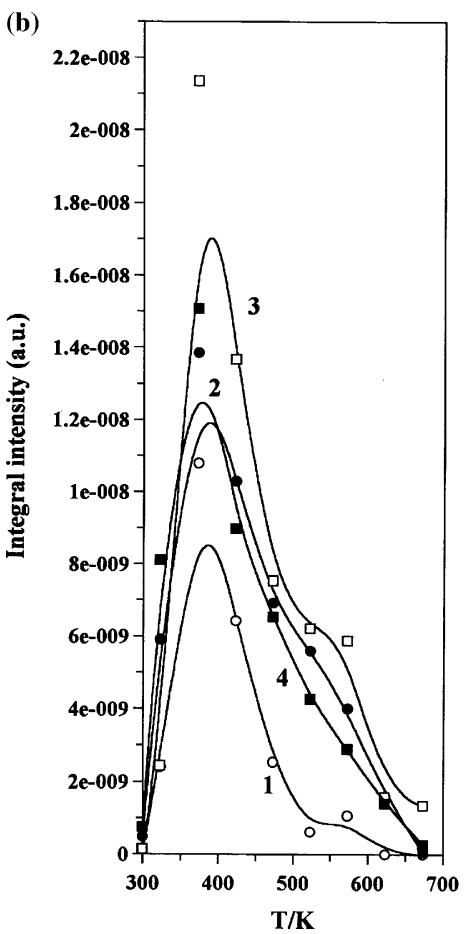

(c)

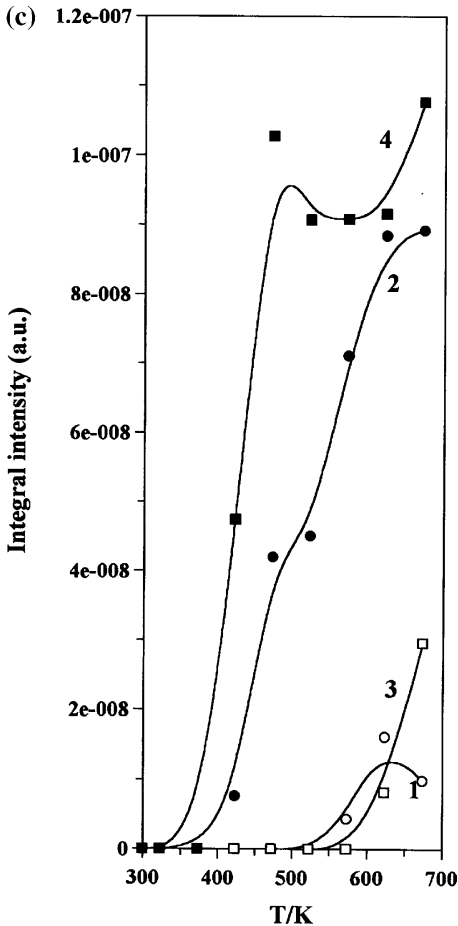

Figure 5. Formation of some gas phase products (monitored by MS) during the heat treatments (see text) of adsorbed acetaldehyde layer on reduced catalysts: $1-\mathrm{Al}_{2} \mathrm{O}_{3} ; 2-1 \% \mathrm{Rh} / \mathrm{Al}_{2} \mathrm{O}_{3} ; 3-1 \% \mathrm{Au} / \mathrm{Al}_{2} \mathrm{O}_{3}$ and $4-1 \% \mathrm{Pt} / \mathrm{Al}_{2} \mathrm{O}_{3}$. (a) hydrogen; (b) ethane and (c) ethylene.

resulting in 2,4-hexadienal and water. According to the explanation of [16] 2,4-hexadienal suffers a $\mathrm{C}-\mathrm{H}$ bond dissociation of its methyl group on $\mathrm{Pt}$, which after intramolecular cyclization followed by $\mathrm{H}_{2} \mathrm{O}$ elimination may give benzene. The first maximum in benzene desorption corresponds well to that of acetaldehyde and crotonaldehyde desorption. The second benzene desorption maximum draws the attention to benzene formation possibly from the strongly held acetaldehyde (bonded to Lewis sites). The band at $3027 \mathrm{~cm}^{-1}$ detected at lower temperatures is tentatively assigned to adsorbed 2,4-hexadienal, while the $3045 \mathrm{~cm}^{-1}$ appearing at higher temperatures is tentatively due to adsorbed benzene (figures 1 and 2).

The strongly held acetaldehyde, on the other hand, may undergo decomposition processes. The appearance of $\mathrm{H}_{2}$ in the gas phase (figure 5a) shows that dehydrogenation occurred above $423 \mathrm{~K}$, at the temperature at which acetaldehyde, crotonaldehyde and benzene desorptions exhibited maximum. $\mathrm{H}_{2}$ formation depended on the nature of the metal: the most effective metal was $\mathrm{Pt}$; on $1 \% \mathrm{Pt} / \mathrm{Al}_{2} \mathrm{O}_{3}$ catalyst $\mathrm{H}_{2}$ evolution started already at $423 \mathrm{~K}$ and its amount was the highest. $\mathrm{Au} / \mathrm{Al}_{2} \mathrm{O}_{3}$ catalyst proved to be the least active, as $\mathrm{H}_{2}$ started to evolve only at $573 \mathrm{~K}$ on this surface.

Ethane formation was detected from all surfaces investigated; $T_{\max }$ of its desorption appeared at about $400 \mathrm{~K}$ (figure $5 \mathrm{~b}$ ). The appearance of ethane as desorption product could be connected with the formation of adsorbed ethoxy (through the reduction of acetaldehyde with the help of protons in surface $\mathrm{OH}$ groups - figures 1 and 2) and the catalytic decomposition of ethanol [14], which could be produced from adsorbed ethoxy. The fact that ethanol was not detected in the gas phase from noble metal containing $\mathrm{Al}_{2} \mathrm{O}_{3}$ catalysts seems to strengthen the above explanation.

Above $T_{\max }$ of ethane desorption ethylene appeared among the gas phase products (figure $5 \mathrm{c}$ ). We think that ethylene may be the product of ethane dehydrogenation; $\mathrm{H}_{2}$ thus produced may contribute to $\mathrm{H}_{2}$ formation in the dehydrogenation of strongly held acetaldehyde (see above).

Next the interaction of acetaldehyde with the reduced catalysts was investigated isothermally. In these experiments the samples were kept in $1.33 \mathrm{hPa}$ acetaldehyde at $300,373,473$ and $573 \mathrm{~K}$ for $60 \mathrm{~min}$ each. The IR spectra were recorded in time at the adsorption temperature and at the same time changes of the gas phase composition were monitored by mass spectrometer.

The IR spectra registered on $1 \% \mathrm{Rh} / \mathrm{Al}_{2} \mathrm{O}_{3}$ after 60 min adsorption at different temperatures were collected in figure 6.

In the ranges of $3100-2600$ and $1800-900 \mathrm{~cm}^{-1}$, respectively, all the bands assigned in connection with figures 1 and 2 appeared already in the first minute at $300 \mathrm{~K}$. The bands of very small intensities at 2010 and $1966 \mathrm{~cm}^{-1}$ were detected at $300 \mathrm{~K}$, which are tentatively assigned to $\mathrm{H}$-perturbed $\mathrm{CO}$ adsorbed on metallic sites. The intensities of these bands increased only slightly in time at $300 \mathrm{~K}$. 

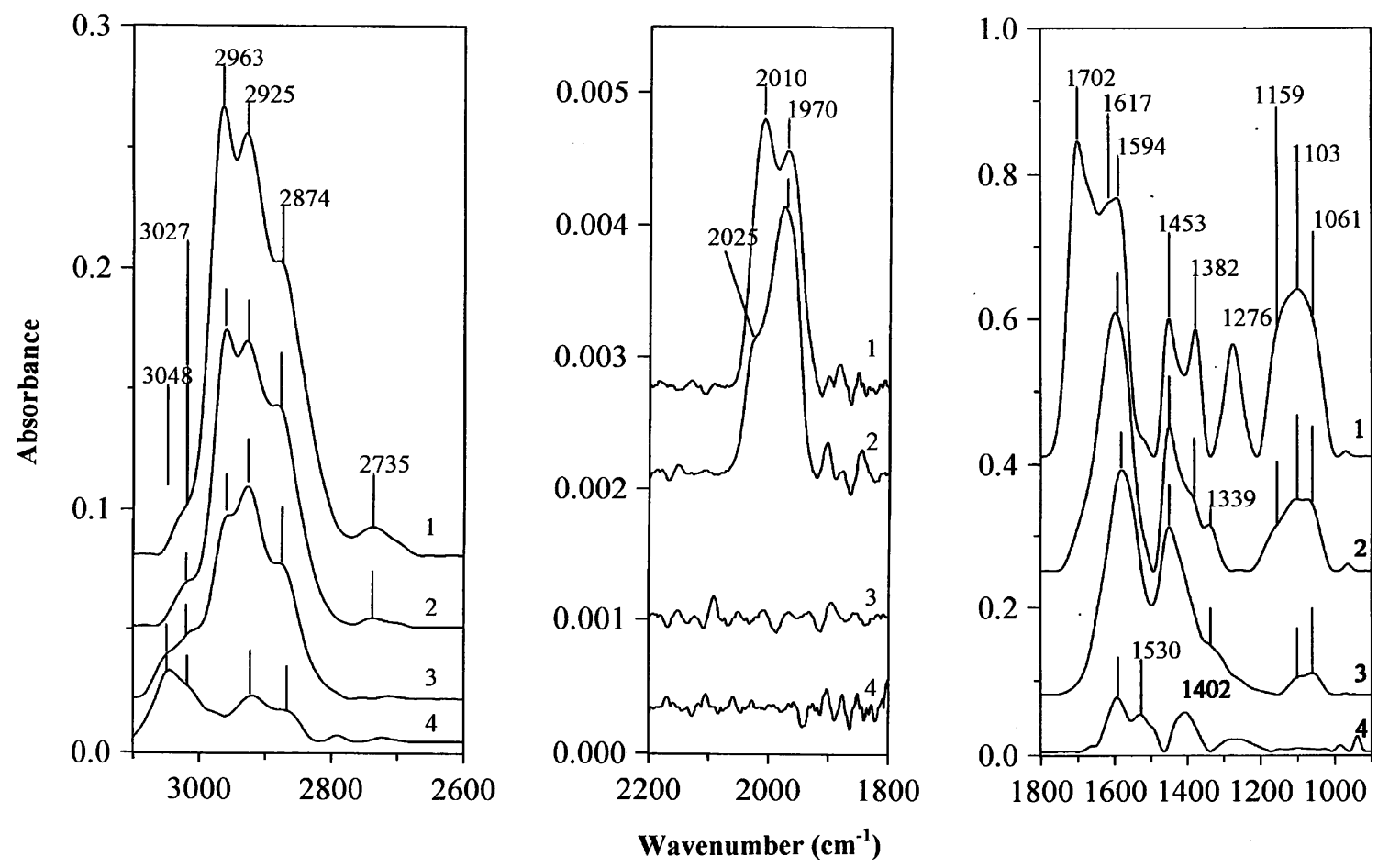

Figure 6. Infrared spectra registered in isotherm experiments after 60 min adsorption of $1.33 \mathrm{hPa}$ acetaldehyde on reduced $1 \% \mathrm{Rh} / \mathrm{Al}_{2} \mathrm{O}_{3}$ : $1-300 \mathrm{~K} ; 2-373 \mathrm{~K} ; 3-473 \mathrm{~K}$ and $4-573 \mathrm{~K}$. The spectra were taken at the adsorption temperatures.

At $373 \mathrm{~K}$ the bands at $1702 \mathrm{~cm}^{-1}(v(\mathrm{C}=\mathrm{O})$ of acetaldehyde), at $1617 \mathrm{~cm}^{-1} v(\mathrm{C}=\mathrm{C})$ of crotonaldehyde $)$ and at $1276 \mathrm{~cm}^{-1}(\delta(\mathrm{C}-\mathrm{H})$ of crotonaldehyde $)$ appeared no more. The intensities of other bands were smaller at $373 \mathrm{~K}$ than at $300 \mathrm{~K}$.

Dramatic changes occurred at and above $473 \mathrm{~K}$ : besides the overall decrease of the bands intensities, a new band at $3048 \mathrm{~cm}^{-1}$ (tentatively assigned to adsorbed benzene) appeared at $473 \mathrm{~K}$, the bands in the 2200 $1800 \mathrm{~cm}^{-1}$ range were not further observed, and in the range of $1800-900 \mathrm{~cm}^{-1}$ the bands due to acetate and carbonates became dominant.

Bands due to H-bridge bonded acetaldehyde could be observed at $300-473 \mathrm{~K}$ in isotherm experiments, at $573 \mathrm{~K}$, however, they were not registered.

The gas phase composition was changed only at 473$573 \mathrm{~K}$. The amount of acetaldehyde in the gas phase decreased only slightly on pure $\mathrm{Al}_{2} \mathrm{O}_{3}$ at $573 \mathrm{~K}$, on noble metal containing catalysts, however, acetaldehyde practically disappeared from the gas phase in $60 \mathrm{~min}$. The highest amount of crotonaldehyde formed in the interaction between $\mathrm{Al}_{2} \mathrm{O}_{3}$ and acetaldehyde at $573 \mathrm{~K}$. Appreciable amount of crotonaldehyde was detected on $1 \% \mathrm{Rh} / \mathrm{Al}_{2} \mathrm{O}_{3}$, and there was practically no crotonaldehyde production on $1 \% \mathrm{Pt} / \mathrm{Al}_{2} \mathrm{O}_{3}$ and $1 \% \mathrm{Au} / \mathrm{Al}_{2} \mathrm{O}_{3}$. The effectiveness order of the catalysts in producing of benzene at $573 \mathrm{~K}$ seems to the opposite of their productivity of crotonaldehyde: the highest amount of benzene was found on $1 \% \mathrm{Au} / \mathrm{Al}_{2} \mathrm{O}_{3}$ and the amount of benzene decreased in the order of $1 \% \mathrm{Au} / \mathrm{Al}_{2} \mathrm{O}_{3}>1 \% \mathrm{Pt} /$ $\mathrm{Al}_{2} \mathrm{O}_{3}>1 \% \mathrm{Rh} / \mathrm{Al}_{2} \mathrm{O}_{3}>\mathrm{Al}_{2} \mathrm{O}_{3}$.
The amount of $\mathrm{H}_{2}$ evolved at $573 \mathrm{~K}$ was also depended on the nature of the metal: the highest amount of $\mathrm{H}_{2}$ was produced on $1 \% \mathrm{Pt} / \mathrm{Al}_{2} \mathrm{O}_{3}$, and the effectiveness of the catalysts in forming of $\mathrm{H}_{2}$ decreased in the order of $1 \% \mathrm{Pt} / \mathrm{Al}_{2} \mathrm{O}_{3}>1 \% \mathrm{Rh} / \mathrm{Al}_{2} \mathrm{O}_{3}>1 \% \mathrm{Au} /$ $\mathrm{Al}_{2} \mathrm{O}_{3}>\mathrm{Al}_{2} \mathrm{O}_{3}$. Ethane formation depended on the temperature and on the nature of the metal. The amount of ethane decreased with the increase of the temperature. On $1 \% \mathrm{Rh} / \mathrm{Al}_{2} \mathrm{O}_{3}$ there was no ethane formation at $573 \mathrm{~K}$. The highest amount of ethane was detected on pure $\mathrm{Al}_{2} \mathrm{O}_{3}$ at $573 \mathrm{~K}$, small amount of ethane was measured on $1 \% \mathrm{Au} / \mathrm{Al}_{2} \mathrm{O}_{3}$ and $1 \% \mathrm{Pt} / \mathrm{Al}_{2} \mathrm{O}_{3}$.

Interestingly, ethylene was not detected among the gas phase products at $300-573 \mathrm{~K}$ in isotherm experiments. Instead of ethylene, small amount of acetylene was detected, as the possible product of ethane dehydrogenation. The amount of acetylene changed parallel with that of ethane as a function of temperature and that of the nature of the metals.

\section{Conclusions}

1. Acetaldehyde adsorbs molecularly on $\mathrm{Al}_{2} \mathrm{O}_{3}$-supported noble metal catalysts through the protons of surface $\mathrm{OH}$ groups forming $\mathrm{H}$-bridge bonding and/or through one of its oxygen lone pairs on surface Lewis sites.

2. Acetaldehyde transforms by $\beta$-aldolization into crotonaldehyde; this transformation depends on the temperature and on the nature of the metal. 
3. At higher temperatures benzene formed via the reaction of acetaldehyde and crotonaldehyde, as well as the dehydrogenation of more stable acetaldehyde proceeded. All these surface processes depended on the nature of the metal.

\section{Acknowledgments}

This work was financially supported by grants OTKA T 46351.

\section{References}

[1] F. Mariño, M. Boveri, G. Baronetti and M. Laborde, Int. J. Hydrogen Energy 26 (2001) 665.

[2] V.V. Galvita, G.L. Semin, V.D. Belyaev, V.A. Semikolenov, P. Tsiakaras and V.A. Solyanin, Appl. Catal. A: Gen. 220 (2001) 123.

[3] C. Diagne, H. Idriss and A. Kiennemann, Catal. Commun. 3 (2002) 565.
[4] V. Klouz, V. Fierro, P. Denton, H. Katz, J.P. Lisse, S. BouvotMauduit and C. Mirodatos, J. Power Sources 105 (2002) 26.

[5] J.P. Breen, R. Burch and H.M. Coleman, Appl. Catal. B: Environ. 39 (2002) 65.

[6] A.N. Fatsikostas, D.I. Kondarides and X.E. Verykios, Catal. Today 75 (2002) 145.

[7] S. Freni, S. Cavallaro, N. Mondello, L. Spadaro and F. Frusteri, J. Power Sources 108 (2002) 53.

[8] V. Fierro, V. Klouz, O. Akdim and C. Mirodatos, Catal. Today 75 (2002) 141.

[9] F. Auprêtre, C. Descorme and D. Duprez, Catal. Commun. 3 (2002) 263.

[10] F. Mariño, G. Baronetti, M. Jobbagy and M. Laborde, Appl. Catal. A: Gen. 238 (2003) 41.

[11] J. Llorca, N. Homs, J. Sales and P. Ramirezdela Priscina, J. Catal. 208 (2002) 306.

[12] P.-Y. Sheng, A. Yee, G.A. Bowmaker and H. Idriss, J. Catal. 208 (2002) 393.

[13] M. Tóth, M. Dömök, J. Raskó, A. Hancz and A. Erdöhelyi, Chem. Eng. Trans. 4 (2004) 229.

[14] J. Raskó, A. Hancz and A. Erdöhelyi, Appl. Catal. A: Gen. 269 (2004) 13.

[15] A.P. Altschuller, Atmos. Environ. 27 (1993) 21.

[16] A. Yee, S.J. Morrison and H. Idriss, J. Catal. 191 (2000) 30. 